\title{
Dominance-diversity, community-coefficient and niche-width relations of woody species in Montane forests of Garhwal Himalaya, India
}

\author{
D. P. SEMWAL ${ }^{1 *}$, P. PARDHA SARADHI ${ }^{1}$ and A. B. BHATT ${ }^{2}$ \\ ${ }^{I}$ Department of Environmental Biology, University of Delhi, Delhi-110 007, India \\ ${ }^{2}$ Department of Botany, H.N.B.Garhwal University, Srinagar, Uttarakhand, India \\ *Corresponding author, Ph. (O)+91-11-27667725, E-mail-dinusem@rediffmail.com
}

\begin{abstract}
The synthetic characters of different plant communities are analysed. Community-coefficient for tree and shrub layer were 89.99 and $\mathbf{8 8 . 4 9 \%}$, respectively in North-West aspect of Cedrus deodara forest, probably due to maximum number of species common to both sites. Among the twelve tree species, only two viz., Cedrus deodara and Cupressus torulosa showed $100 \%$ presence amongst all the sites. The maximum equitability (10.47) value was computed in site five, because of similar type of species found in this site. Cedrus deodara (6.34) and Cupressus torulosa (5.54) had broader niches due to their presence at all the sites. Species diversity was highest (3.22) on the North West (NW) aspect of the V site and was directly related to the high density of tree species in this site. Dominance-diversity curve ( $d-d$ curve) for the tree layer and shrub layer, based on Importance Value Index (IVI) exhibited a geometric series for all forest sites except site IV, where it reflected Preston's log normal models. The log normal distribution of this site indicated the mixed nature of vegetation. These species are gradually loosing their niche width, density, dominance and diversity in different sites because of over exploitation and over grazing pressure on these species. In view of the great anthropogenic pressure on the plant community, conservation and management measures are required for sustainable use of these important ethnobotanical plant species and plant biodiversity protection.

(C) 2007 International Formulae Group. All rights reserved.
\end{abstract}

Keywords: Community structure, conservation, concentration of dominance (Cd), diversity, sustainable utilization.

\section{INTRODUCTION}

The Western Himalaya (including Uttarakhand, Himachal and Jammu and Kashmir regions), although dry and less dense as compared to the Eastern Himalaya, is still one of the rich botanical regions of India (Singh and Singh, 1992). It supports highly diversed vegetation types and the three vegetation zones, the sub-montane zone (at elevation up to $1,500 \mathrm{~m}$ ), the montane zone (occupying the elevation ranging from 1,500$3,000 \mathrm{~m}$ ) and the alpine zone located above 3,000 $\mathrm{m}$ from sea level (Meher-Homji, 1978).

The Garhwal Himalayan forests, a part of Western Himalaya, vary altitudinally, have various distributed dominant species ranging from Shorea robusta in sub-montane zone to Quercus leucotrichophora, Pinus roxburghii and Cedrus deodara in the montane zone and Quercus semicarpifolia, Betula utilis, Rhododendron campanulatum, near timber line (Semwal and Gaur, 1981). Ecological studies in terms of phytosociological features for different forests of Himalaya are available (Adhikari et al., 1991; Bisht and Kusumlata, 1993; Ram et al., 2004; Saxena and Singh 1982; Semwal and Bhatt, 1997; Sharma and Singh, 2000). There are many remote areas in the Garhwal Himalaya that contain rich plant diversity and their dominance-diversity, niche width and $P \times F$, remain lesser investigated in relation with other plant 
species.

Forests and forest ecosystems of Garhwal Himalaya are under severe pressures, both from biotic and abiotic factors, due to high anthropogenic activities and soil degradation caused by grazing, felling, removal of forest floor litter and forest fire (Singh and Singh, 1992; Semwal, 1994). Therefore, there is an urgent need of research particularly in quantitative terms to give actual status of different woody species in the Himalayan region. In the present study an attempt has been undertaken for analyzing Niche width (NW), per cent presence (PP), average frequency (AF) and presence $x$ frequency $(P \times F)$ indices, communitycoefficient and dominance- diversity relations in different sites of moist temperate forests in the montane zone $(1500-2200 \mathrm{~m}$ amsl) of Garhwal Himalaya.

\section{MATERIALS AND METHODS}

The investigations were undertaken in the montane zone $(1500-3000 \mathrm{~m}$ amsl) of district Rudraprayag and Pauri (Figure 1) in Garhwal Himalaya (Lat. $29^{\circ} 26^{\prime}-31^{\circ} 28^{\prime} \mathrm{N}$ and Long. $77^{\circ} 48^{\prime}-80^{\circ} 06^{\prime} \mathrm{E}$ ) during the period 2003 to 2005 . A total of eight sub-sites, with varying altitude and physiographic aspects were selected for the present study. The first site (Ghimtoli) was selected between the rivers Mandakini and Alaknanda and the second site (Nagdev, Pauri) is situated south of the river Alaknanda and west of the river Nayyar. We have given detail characteristic features of study area in Table 1.

The climate is influenced by monsoon pattern of rainfall. The year is divisible into four season viz; summer (April to mid June), rainy (mid June to September), winter (November to Febraury) and spring (March). October constitutes the transition month between the rainy season and winter season. Rainy season is the wettest period of the year. The area receives more than $200 \mathrm{~cm}$ of annual precipitation of which the rainy months (midJune to September) contribute approximately $60 \%$. The relative humidity varies from 35 to 80 per cent annually. There is moderate to heavy snowfall during December-February. The mean monthly minimum temperature ranges between $2{ }^{\circ} \mathrm{C}$ (January) and $14.0{ }^{\circ} \mathrm{C}$ (June) and mean maximum temperature ranges between $5.0^{\circ} \mathrm{C}$ (January) and $22^{\circ} \mathrm{C}$ in June (Semwal and Bhatt, 1994). The random sampling of vegetation was made using the quadrat method (Misra, 1968). For estimating frequency, density and dominance we have selected two vertical belts transacts of size $100 \mathrm{~m}$ long and $80 \mathrm{~m}$ wide (Misra, 1968).

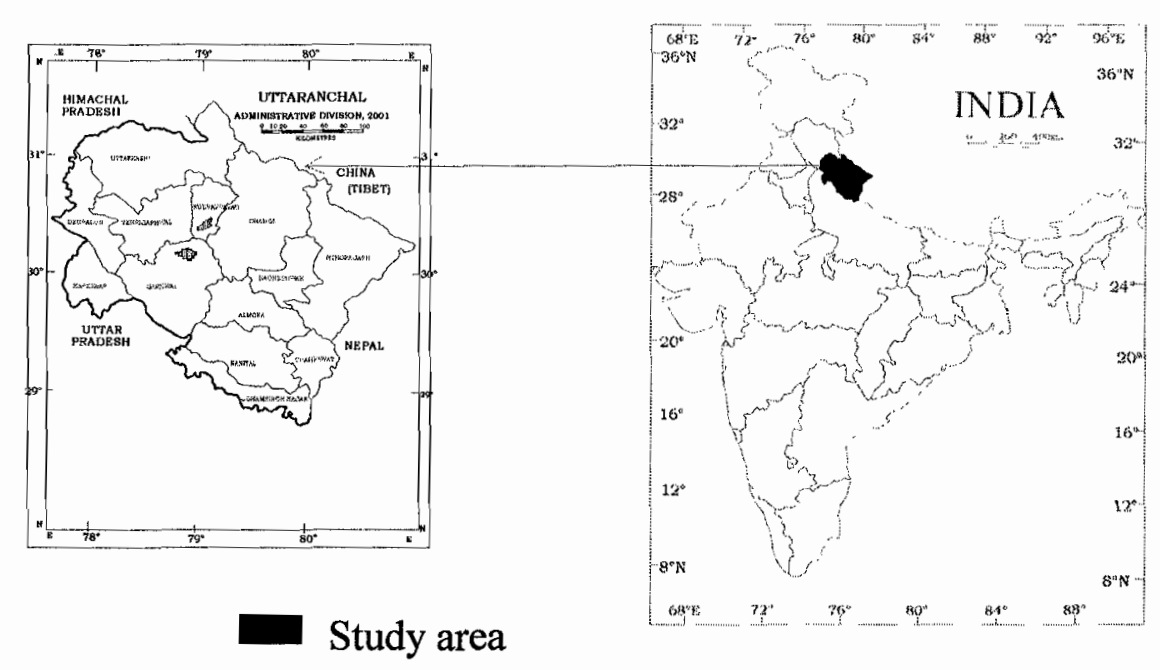

Figure 1: Location map of study area 
Table 1: Detailed site characteristics of the study area in Garhwal Himalaya, India.

\begin{tabular}{llllll}
\hline Sites & $\begin{array}{l}\text { Name of forest } \\
\text { sites }\end{array}$ & $\begin{array}{l}\text { Altitude } \\
(\mathbf{m})\end{array}$ & $\begin{array}{l}\text { Slope angle } \\
\text { \& direction }\end{array}$ & $\begin{array}{l}\text { Total } \\
\text { area (ha) }\end{array}$ & Forest Types \\
\hline (1) District & & & & & \\
Rudraprayag & Naini devi & 2000 & $41^{\circ} \mathrm{NE}$ & 20 & $\begin{array}{l}\text { Mixed forest } \\
\text { I }\end{array}$ \\
II & Nainidanda & 2100 & $38^{\circ} \mathrm{NW}$ & 20 & $\begin{array}{l}\text { Cedrus deodara } \\
\text { III }\end{array}$ \\
Kharpatiya & 1950 & $45^{\circ} \mathrm{SE}$ & 20 & Cedrus deodara \\
IV & Hill top & 2150 & $40^{\circ} \mathrm{NW}$ & 20 & Mixed forest \\
V & Hill base & 1800 & $35^{\circ} \mathrm{NW}$ & 20 & \\
(2) District & & & & & Cedrus deodara \\
Pauri & & & & 20 & Cedrus deodara \\
VI & Nagdev upper & 2000 & $46^{\circ} \mathrm{NW}$ & 20 & Mixed forest \\
VII & Nagdev middle & 1900 & $26^{\circ} \mathrm{EAST}$ & 20 & \\
VIII & Nagdev lower & 1800 & $31^{\circ} \mathrm{SE}$ & & \\
\hline
\end{tabular}

One hundred and sixty quadrats of $10 \times 10 \mathrm{~m}^{2}$ for tree species and $5 \times 5 \mathrm{~m}^{2}$ in the same transact for shrubs, located in a representative portion of the forest sites, giving a total sampling area of 16 ha. Circumference at breast height $(\mathrm{CBH})$ of all the trees in each quadrat was measured and recorded individually for different species. Plants with circumference breast height (Cbh) more than $31.5 \mathrm{~cm}$ were considered trees and those with 10.5-31.4 $\mathrm{cm}$ were considered as shrubs. The vegetational data were quantitatively analysed for phytosociological parameters like frequency, density, importance value index (IVI) and total basal cover (Curtis and McIntosh, 1950; Curtis, 1959; Knight, 1975). Shannon's and Simpson's indices were used to evaluate diversity and dominance of two and more than two species in a particular site.

The following formulae were used for calculating diversity and dominance (Shannon and Weaver, 1963; Magurran, 1988). The species or general diversity $(\mathrm{H})$ is calculated as follows: $H=\sum^{s} i=1(n i / N) \log _{2}(n i / N)$, whereas the concentration of dominance (Cd) is calculated as follows:

$\mathrm{Cd}=\sum_{\mathrm{i}=1}^{\mathrm{s}}(\mathrm{ni} / \mathrm{N})^{2}$; Where $\mathrm{ni}$ is the density/TBC/IVI values of a particular species; $\mathrm{N}$ is the total density/TBC/IVI values of all the species.

For the comparison of different forest species in different sites, communitycoefficient was calculated on the basis of Importance Value Index (IVI) and Niche width for each tree and shrub species was computed using the equation as given by Levins (1968).

Niche width $\Sigma_{\mathrm{i}} \mathrm{Nij}=\left(\Sigma_{\mathrm{i}} \mathrm{Nij}\right)^{2} / \Sigma \mathrm{iNij}$, where
$\mathrm{Nij}$ is density value for species on site $\mathrm{j}$.

The $\mathrm{P}$ x F (Presence $x$ Frequency) index was also computed for all woody species to represent the importance of species for the area (Curtis, 1959). Equitability (EC) or species per log cycle index was determined by Whittaker (1972). Dominance-diversity curve (d-d curve) was drawn by plotting the $\log$ transformed importance values (IVI) of trees and shrubs against the rank of the species in importance. Mostly these curves followed the geometric series confirming with niche pre-emption hypothesis proposed by Magurran (1988) and Singh and Singh (1992).

\section{RESULTS}

Phytosociological parameters, analyzed in terms of quantitative data (analytic and synthetic), play very important role in recognizing their distribution pattern and status in the forest community (Ram et al., 2004). They also give the quantitative assessment on similarity among the species of a particular region. Cedrus deodara dominated the forest present in sites second and fourth, both situated in North-West (NW) aspects, as it favours moist places and even grows in high altitude areas of Himalaya because it is the characteristic features of this species. It shows high similarity value of $89.9 \%$ as compared to other tree species. This is because of maximum number of trees species common at both sites. The community-coefficient or similarity index of different species among other sites ranged between 33.71 to $70.6 \%$ (Table 2). The lack of similarity may reflect the striking 
Table 2: Community-coefficient (in \%) among different sites of woody species (Trees and Shrubs) in moist temperate forests of Garhwal Himalayas, India.

\begin{tabular}{|c|c|c|c|c|c|c|c|c|}
\hline \multicolumn{9}{|c|}{ Trees } \\
\hline Sites & I & II & III & IV & $\mathrm{V}$ & VI & VII & VIII \\
\hline I & 100 & 49.00 & 70.60 & 49.77 & 60.89 & 57.52 & 51.48 & 51.58 \\
\hline II & & 100 & 67.35 & 89.99 & 69.70 & 69.96 & 62.29 & 49.39 \\
\hline III & & & 100 & 63.78 & 72.96 & 52.07 & 43.32 & 38.93 \\
\hline IV & & & & 100 & 75.34 & 69.08 & 57.25 & 49.06 \\
\hline V & & & & & 100 & 31.19 & 33.28 & 33.71 \\
\hline VI & & & & & & 100 & 84.50 & 70.34 \\
\hline VII & & & & & & & 100 & 64.40 \\
\hline VIII & & & & & & & & 100 \\
\hline \multicolumn{9}{|c|}{ Shrubs } \\
\hline I & 100 & 35.27 & 75.07 & 25.38 & 61.07 & 53.78 & 46.42 & 55.37 \\
\hline II & & 100 & 26.73 & 88.49 & 64.84 & 27.66 & 27.66 & 25.75 \\
\hline III & & & 100 & 32.28 & 61.48 & 43.98 & 36.62 & 52.25 \\
\hline IV & & & & 100 & 54.87 & 23.88 & 23.88 & 22.69 \\
\hline V & & & & & 100 & 55.00 & 40.09 & 41.71 \\
\hline VI & & & & & & 100 & 79.94 & 70.03 \\
\hline VII & & & & & & & 100 & 68.04 \\
\hline VIII & & & & & & & & 100 \\
\hline
\end{tabular}

variation in the micro-climatic conditions (Whittaker, 1965). Thus, the values of community-coefficient also fall in the range of values reported for earlier studies in Central Himalayan forests (Singh and Singh, 1992). Cedrus deodara (6.34) and Cupressus torulosa (5.54) exhibited a broader niche width as compared to other tree species (Table 3) because these two species were found in all the sites. Pinus roxburghii, Myrica esculenta and Rhododendron arboreum had narrow niche (1.03) due to their presence at only one site.

Among the twelve tree species only two, $C$. deodara and $C$. torulosa, showed $100 \%$ presence while other species displayed presence value fluctuating between 12.5 and $75 \%$. The maximum average frequency was computed for $C$. deodara $(88.75 \%)$ followed by Cupresuss torulosa $(70.00 \%)$, while minimum average frequency was recorded for Pinus wallichiana (30.0\%). Cedrus deodara and Cupresuss torulosa exhibited higher values of Presence $x$ Frequency $(P \times F)$ i.e. 8875.0 and 7000.0 respectively, mainly due to dominant nature of these two species in the study area. The least value of $P \times F$ was computed for Myrica esculenta (1000.0). The values of species diversity and concentration of dominance $(\mathrm{Cd})$ in tree stratum varied between 1.24 to 3.22 and 0.14 to 0.39 , respectively among all the eight sites. Site seven exhibit minimum diversity $(\mathrm{H}=1.52)$ and site five showed maximum diversity $(\mathrm{H}=3.22)$ (Table 4). It is apparent that maximum diversity values were found for those sites which are far from habitation area (Site V) as compared to other sites. This is because of high anthropogenic activities in the lower altitude of study area. Species richness ( $\alpha$-diversity) and $\beta$-diversity for the tree layer ranged between $4.0-10.0$ and 1.42 2.15 , respectively. The maximum equitability (10.47) value was computed in site five, because of maximum number of species found in this site. Dominance-diversity curve (d-d curve) for the tree layer showed a geometric series for all forest sites except site four (Figures $2 \& 3$ ). The $\log$ normal distribution of species in these sites indicated the mixed nature of vegetation and high slope angle and altitudinal variations among the sites. Shrubs are also important constituents of the forest communities, because these small plants play very important role in identifying associations and status with other plant communities.

Broader range of niche width was observed in shrubs like Berberis asiatica (5.15) and Pyracantha crenulata (4.70); 
Table 3: Niche Width (NW), Per cent Presence (PP), Average Frequency (AF) and Presence $x$ Frequency $(P \times F)$ index of woody species in moist temperate forests of Garhwal Himalayas, India.

\begin{tabular}{lllll}
\hline Species Name & NW & PP & AF & P $\times \mathbf{F}$ \\
\hline Tree Layer & & & & \\
Aesculus indica (Wall.)Hook. & 1.59 & 37.50 & 46.66 & 1749.75 \\
Cedrus deodara (Royle ex. D.Don) & 6.34 & 100.00 & 88.75 & 8875.00 \\
Cupressus torulosa D.Don & 5.54 & 100.00 & 70.00 & 7000.00 \\
Fraxinus micrantha L. & 2.09 & 37.50 & 40.00 & 1500.00 \\
Juglans regia L. & 1.48 & 50.00 & 40.00 & 2000.00 \\
Lyonia ovalifolia (Wall.) Drude & 2.19 & 50.00 & 40.00 & 2300.00 \\
Myrica esculenta D.Don & 1.00 & 25.00 & 40.00 & 1000.00 \\
Pinus wallichiana Jacks. & 4.52 & 75.00 & 30.00 & 5499.75 \\
Pinus roxburghii Sarg. & 1.00 & 12.50 & 33.33 & 3075.00 \\
Quercus dilatata Lindl. & 2.26 & 75.00 & 37.50 & 2499.75 \\
Rhododendron arboreum Sm. & 1.09 & 50.00 & 50.00 & 1875.00 \\
Taxus wallichiana Zucc. & 3.34 & 62.50 & 50.00 & 3125.00 \\
& & & & \\
Shrub Layer & & & & \\
Berberis asiatica Roxb.ex.DC. & 5.15 & 100.00 & 66.25 & 6625.00 \\
Caesalpinea decapetala Roth. & 1.06 & 37.50 & 63.30 & 2374.87 \\
Cotoneaster microphyllus Wall. & 4.02 & 100.00 & 68.75 & 6875.00 \\
Daphne papyracea Wall ex.Steud. & 2.20 & 37.50 & 53.33 & 1999.87 \\
Litsea pallens (D.Don). & 2.51 & 50.00 & 62.50 & 3125.00 \\
Principia utilis Royle. & 3.32 & 75.00 & 51.66 & 3874.50 \\
Pyracantha crenulata (D.Don). & 4.70 & 100.00 & 70.00 & 7000.00 \\
Randia tetrasperma (Roxb.) & 1.02 & 50.00 & 50.00 & 2500.00 \\
Rosa bruniana Lindl. & 1.63 & 37.50 & 50.00 & 1875.00 \\
Rubus ellipticus Sm. & 2.95 & 25.50 & 45.00 & 1125.00 \\
Rubus lasiocarpus Sm. & 1.00 & 12.50 & 40.00 & 5000.00 \\
Spirea canescence D.Don & 1.11 & 50.00 & 55.00 & 2750.00 \\
\hline & & & & \\
& & & &
\end{tabular}

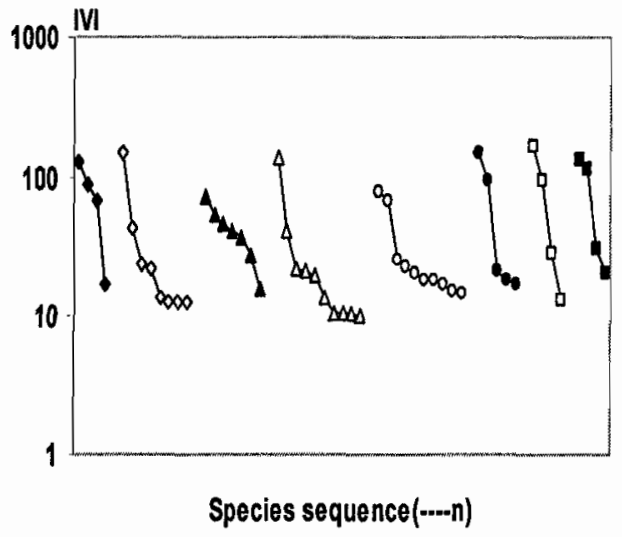

Figure 2: Dominance-diversity curve for different tree species in moist temperate forests of Garhwal Himalayas, India. (Sites 18 are arranged from left to right).

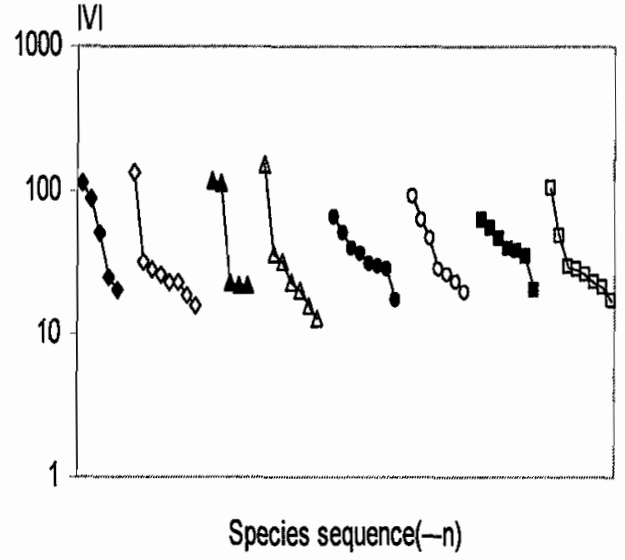

Figure 3: Dominance-diversity curve for different shrub species in moist temperate forests of Garhwal Himalayas, India. (Sites 18 are arranged from left to right). 
Table 4: Concentration of dominance $(\mathrm{Cd})$, diversity index $(\mathrm{H})$, alpha diversity $(\alpha d)$ beta diversity $(\beta d)$ and equitability $(\mathrm{Ec})$ of woody species in different sites of moist temperate forests of Garhwal Himalayas, India.

\begin{tabular}{llllll}
\hline SITES /layers & CD & H & QD & $\beta D$ & EC \\
\hline I & & & & & \\
Trees & 0.31 & 1.26 & 4 & 1.42 & 3.55 \\
Shrubs & 0.26 & 1.95 & 5 & 1.28 & 5.31 \\
II & & & & & \\
Trees & 0.29 & 2.10 & 9 & 2.30 & 6.67 \\
Shrubs & 0.22 & 2.22 & 8 & 1.95 & 7.80 \\
III & & & & & \\
Trees & 0.17 & 2.17 & 7 & 1.75 & 9.62 \\
Shrubs & 0.33 & 1.40 & 5 & 1.61 & 5.91 \\
IV & & & & & \\
Trees & 0.27 & 2.10 & 10 & 2.17 & 7.09 \\
Shrubs & 0.28 & 2.17 & 7 & 2.00 & 5.61 \\
V & & & & & \\
Trees & 0.14 & 3.22 & 10 & 1.53 & 10.47 \\
Shrubs & 0.13 & 2.60 & 8 & 1.53 & 13.93 \\
VI & & & & & \\
Trees & 0.36 & 1.78 & 4 & 1.78 & 4.68 \\
Shrubs & 0.17 & 1.58 & 7 & 1.94 & 8.38 \\
VII & & & & & \\
Trees & 0.39 & 1.52 & 4 & 1.66 & 4.26 \\
Shrubs & 0.14 & 2.15 & 7 & 1.34 & 9.38 \\
VIII & & & & & \\
Trees & 0.35 & 1.24 & 4 & 1.60 & 4.42 \\
Shrubs & 0.18 & 2.08 & 8 & 1.77 & 8.77 \\
\hline
\end{tabular}

mainly these two species were found in all the sites while Rubus lasiocarpus (1.0) had a comparatively narrow niche width (Table 3 ). Among the different species of shrubs, only three species i.e. Berberis asiatica, Cotoneaster microphyllus and P. crenulata displayed $100 \%$ presence while other species ranged between 12.5 to $75.0 \%$ presence. The maximum average frequency was computed for $P$. crenulata $(70 \%)$ followed by $C$. microphyllus $(68.75 \%)$, while minimum average frequency was calculated for $R$. lasiocarpus $(40 \%)$. P $\times$ F values of $P$. crenulata and C. microphyllus were 7000.0 and 6875.0, respectively. The minimum $\mathrm{P} \times \mathrm{F}$ value was computed for $R$. ellipticus (1125.0). The $d-d$ curves for the shrub layer constructed on the basis of density were similar to those of the tree layer. The hill base forests experienced excessive lopping, felling and grazing that resulted in the degradation of soil, and decrease in the plant species richness. The shrub species followed a similar course in all the sites. The values for concentration of dominance are inverse to those of diversity. Alpha $(\alpha)$ diversity always gives the actual number of total species in a particular site. $\alpha$ Diversity and $\beta$-diversity values ranged from 5.0-8.0 and 1.28 to 2.0 respectively for shrub species. It was observed that $\beta$-diversity shows an intercommunity diversity which expresses the rate of species per unit change in a particular habitat (Ram et al., 2004). Equitability and variation in the environmental conditions is manifested due to changes in elevation. This is reflected in the high $\beta$-diversity of the vegetation. Thus, the values of $\beta$-diversity also fall in the range of values reported earlier for temperate forests of the world (Singh and Singh, 1992; Knight, 1975; Whittaker, 1972).

Niche width measures the degree of specialization of a species as its ability to exploit an environmental range in a space and maintaining its population in different 
environments. According to Monk (1967) the species with wider niches are considered to be more generalized, while those with narrow niches are able to utilize a wide range of resources. Broader range of niche width of tree species was noticed for Rhododendron arboreum (9.74) and Pinus roxburghii (5.52) of moist temperate forests of Himalaya (Bisht and Kusumlata, 1993). In oak forests of this region (1700-2400 m) Saxena and Singh (1982) and Tewari and Singh (1981) reported high species richness (4.0-22.0) and diversity (0.74-3.10) for tree and shrub layer which is more to temperate forest of the present study area. The low values of species richness and diversity may be due to greater shade under these forests and high anthropogenic activities in the region. Whittaker $(1972,1965)$ suggested that the dominance of one stratum might affect the diversity of another stratum. Dominance-diversity curve (d-d curve) for the tree layer (based on IVI) found a geometric series for all forest sites except site four, where it reflected log normal models (Preston's, 1948). The d-d curves for the shrub layer constructed on the basis of density were similar to those of the tree layer. The geometric series for both layers confirmed the niche pre-emption hypothesis of Singh and Singh $(1987,1992)$.

\section{DISCUSSION}

Analysis of quantitative features (analytic and synthetic characters) showed that, most of the species had low values of different synthetic characters probably due to presence of most of the multi-purpose species (Cedrus deodara, Quercus dilatata, Rhododendron arboreum, and Taxus wallichiana) and high anthropogenic activities in the study area. It was observed that woody species had less niche width, density, dominance and diversity values in different sites because of over grazing, lopping for fuel, fodders and removal of forest floor litter. Shrinking of a community has an effect on the other plant and animal communities and influences the biotic diversity, and the rescue effect will be decreased. Another most important reason behind the low values could be degradation of soil and over exploitation of plant species in the region. This is attributed to traditional forest management system, which is timber oriented. We propose better understanding should be developed between forest department authorities and local people for its management and sustainable utilization of these plant species in natural forests. It is also suggested that villages around the forest area particularly in the Himalayan region should be supported by modern fuel, electricity, biofertilizers and environmental education. They should be promoted to plant the native species in the vicinity of the villages. It would be definitely helpful to involve locals in environmental awareness and conservation programme (s) for protection of vegetation as well as clean environment in the region.

\section{ACKNOWLEDGEMENTS}

DPS is grateful to CSIR and Department of Science \& Technology, Govt. of India, for the award of Young Scientist project. This work is financially supported by the Department of Science and Technology, Govt. of India, New Delhi. We thank Prof. R.D. Gaur, University of Garhwal, Srinagar for identification of specimens.

\section{REFERENCES}

Adhikari BS, Rikhari HC, Singh SP. 1991. High altitude forest; Composition, diversity and profile structure in a part of Kumaun Himalaya. Trop. Ecol., 32: 8697.

Bisht NS, Kusumlata. 1993. Niche width and dominance diversity relations of woody species in a moist temperate forest of Garhwal Himalaya. J. Hill Res., 6: 107113.

Curtis JT, McIntosh RP. 1950. The interrelations of certain analytic and synthetic phytosociological characters. Ecology 31: 434-455.

Curtis JT. 1959. The vegetation of Wisconsin. An Ordination of Plant Communities. University of Wisconsin Press. Madison, Wisconsin, USA.

Knight DH. 1975. A Phytosociological analysis of species rich tropical forest on Barro Colorado Island. Panama. Ecol. Monogr. 45: 259-284.

Levins R. 1968. Evolution in changing Environments. Princeton University Press, Princeton.

Magurran AE. 1988. Ecological diversity and its Measurement: Croom Helm: London 
Meher-Homji VM. 1978. Vegetation classification. Need we disseminate environmental terminologies from the physiognomic nomenclature. Ind. For., 104: 653-660.

Misra R. 1968. Ecology Work Book. Oxford \& IBH Publications: New Delhi

Monk CD. 1967. The species diversity in the eastern deciduous forest with particular reference to North Central Florida. Amer. Naturalist, 101: 173-187.

Prestons FW. 1948. The commonness and rarity of species. Ecology, 29: 254-283.

Ram J, Kumar A, Bhatt J. 2004. Plant Diversity in six forest types of Uttaranchal, Central Himalaya, India. Curr. Sci., 86, 7: 975-978.

Rawat YS, Singh JS. 1989. Structure and function of Oak forests in Central Himalaya. Dry Matter Dynamics. Ann. Bot., 62: 397-411.

Saxena AK, Singh JS.1982. A Phytosociological analysis of woody species in forest communities of a part of Kumaun Himalaya. Vegetatio, 50: 3-22.

Semwal DP, Bhatt AB. 1994. Impact of biotic stress on composition and structure of some temperate forest in Garhwal Himalaya. $J$. Hill Res., 7(1): 17-22.

Semwal DP, Bhatt AB. 1997. Analysis of woody vegetation in a high elevation
Deodar forest of Central Himalaya. $J$. Indian Bot. Soc., 76, 177-180.

Shannon CE, Weaver W. 1963. The mathematical theory of Communication, University of lllinois Press, Urbana, USA.

Sharma JR, Singh DK. 2000. Status of plant Diversity in India: An overview. In Biodiversity and Environment (Eds. P.S.Roy) IIRS Publication, Dehradun. pp. 215.

Singh JS, Singh SP. 1992. Forests of Himalaya: Structure, Functioning and Impact of man: Gynodaya Prakashan: Nainital, India.

Singh, JS, Singh SP. 1987. Forest Vegetation of the Himalaya. Botanical Review, 53 (1): 80-191.

Tewari JC, Singh SP. 1981. Vegetational analysis of a forest lying in transitional zone between lower and upper Himalayan moist temperate forest. In The vegetational wealth of the Himalaya, Paliwal GS (ed). Puja Publishers: New Delhi; 104-119.

Whittaker RH. 1965. Dominance and Diversity in land plant communities. Science, 147: 250-260.

Whittaker RH. 1972. Evolution and measurement of species diversity. Taxon, 21: $213-251$. 